PROC. OF JSCE

No. 337, September 1983

\title{
BENDING ANALYSIS OF STRAIN-SOFTENING BEAMS
}

\author{
By Keïchiro SONODA*
}

\section{INTRODUCTION}

It is well known that materials such as concrete, soil and rock exhibit a strain softening behaviour after reaching a peak stress in compressive tests. For example, the stress-strain curve of a concrete in standard cylinder tests rises to a strain about $0.25 \%$ and afterward falls gradually to a strain about $0.35 \%$ when a crushing failure occurs. Since a strain softening is a phenomenon of physical instability, in an analysis of the structures made of strain softening materials, a question about stability and uniqueness of solution arises.

For example, in a finite element displacement analysis, a final matrix equation between the unknown nodal displacements or forces, $\boldsymbol{P}$, and the imposed nodal forces or displacements, $\boldsymbol{u}$, under consideration of prescribed boundary conditions is given as

$$
\boldsymbol{P}=\boldsymbol{K} \boldsymbol{u}
$$

If the overall stiffness matrix $\boldsymbol{K}$ is positive definite, a solution of Eq. (1) can uniquely be determined from

$$
\boldsymbol{u}=\boldsymbol{K}^{-1} \boldsymbol{P}
$$

But, in the case where $\boldsymbol{K}$ is not positive definite, Eq. (2) does not give a stable equilibrium solution making a total potential energy of system minimum, because the function of strain energy loses its convexity. Concerning this problem, a stability condition of strain softening structures was discussed by Prevost \& Hoeg ${ }^{1)}$ for a three dimensional body and $\mathrm{Maier}^{2)}$ for a beam.

On the other hand, for reasons of the urgent necessity of solving some engineering problems of soil foundations, rock foundations and concrete structures, various numerical analyses of strain softening structures have been carried out ${ }^{3(2)}(6), 9,10$ ), though a question mentioned above remains open. To determine load carrying capacities of such structures is one of the most important engineering problems. If regions

* Member of JSCE, Dr. Eng., Professor of Civil Engineering, Osaka City University. exhibiting strain softening are relatively small and are confined by strong surrounding elastic constraints, as often encountered in practical problems, the structures may withstand still higher loads as a stable structure after the strain energy stored within the regions of strain softening was perfectly released. For an analysis of such problems, an appropriate treatment of local instability due to strain softening becomes very important.

From such a viewpoint, this paper has an attempt to obtain a method of analysis of elasticplastic-strain softening beams. The method is developed with the aid of a minimum principle of strain energy-increment, using a matrix displacement method. A detailed procedure of numerical calculation is described through a simple example of a two-span beam.

\section{MINIMUM PRINCIPLE OF STRAIN ENERGY-INCREMENT}

A minimum principle of energy says that an equilibrating solution exists at the point making a total potential of system minimum among any kinematically admissible displacement fields. Such a potential is expressed, in the absence of body forces, as follows:

$$
\pi=\int_{V} W\left(\varepsilon_{i j}\right) d V-\int_{S_{t}} T_{j} u_{j} d S
$$

where $\varepsilon_{i j}$ is strain tensor, $W\left(\varepsilon_{i j}\right)$ is strain energy, $T_{j}, u_{j}$ are surface force and displacement, $S_{t}$ is the boundary surface subjected to $T_{j}$, and $V$ is the entire body considered here. When the body is subjected to a small change of the external agency from $\left(T_{j}, u_{j}\right)$ to $\left(T_{j}+d T_{j}, u_{j}+d u_{j}\right)$, Eq. (3) yields

$$
\begin{aligned}
\pi+d \pi= & \int_{V} W\left(\varepsilon_{i j}+d \varepsilon_{i j}\right) d V \\
& -\int_{S_{t}}\left(T_{j}+d T_{j}\right)\left(u_{j}+d u_{j}\right) d S
\end{aligned}
$$

From Eqs. (3) and (4), we obtain

$$
\begin{aligned}
d \pi= & \int_{V}\left[\frac{\partial W}{\partial \varepsilon_{i j}} d \varepsilon_{i j}+f\left(d \varepsilon_{i j}\right)\right] d V \\
& -\int_{S_{t}}\left[T_{j} d u_{j}+d T_{j}\left(u_{j}+d u_{j}\right)\right] d S \cdots \cdots \cdots(
\end{aligned}
$$


where $f\left(d \varepsilon_{i j}\right)$ is the strain energy being of higher order than the second order.

Using the stationary condition, $\delta \pi=0$, minimizing of $d \pi$ in a displacement field is reduced to that of $\mathrm{d} \pi^{\prime}$ as follows:

$$
d \pi^{\prime}=\int_{V} f\left(d \varepsilon_{i j}\right) d V-\int_{S_{t}} d T_{j}\left(u_{j}+d u_{j}\right) d S
$$

Generally, for a numerical analysis of strain softening structures, the use of controlling a displacement-increment on the surface $S_{t}$ is more convenient than that of controlling load-increment on it, because of relaxing a numerical instability due to a strain softening effect. Here, introducing an incremental multiplier of load denoted by

$$
d \lambda=d T_{j} / T_{j}{ }^{0}
$$

where $T_{j}^{0}$ is a normalized load distribution, a controlled displacement-increment is given as

$$
d L=\int_{S_{t}} T_{j}^{0} d u_{j} d S
$$

Thus, minimizing of $d \pi^{\prime}$ in Eq. (6) is reduced to

$$
\begin{aligned}
& \text { minimize } \\
& \qquad \int_{V} f\left(d \varepsilon_{i j}\right) d V \\
& \text { subject to } \\
& \quad \int_{S_{t}} T_{j^{0}} d u j d S=d L
\end{aligned}
$$

Finally, using a solution $d \varepsilon_{i j}{ }^{*}$ of Prob. (9), from the principle of virtual work, we obtain

$$
d \lambda=\left.\frac{1}{d L} \int_{V} \frac{\partial f}{\partial\left(d \varepsilon_{i j}\right)}\right|_{d \varepsilon_{i j}=d \varepsilon_{i j} j^{*}} \cdot d \varepsilon_{i j} * d V \cdots \cdots
$$

\section{BENDING ANALYSIS OF BEAMS}

Let us consider a beam with a cross sectional property whose moment-curvature relation is given by a bilinear curve shown in Fig. 1. But, when such strain softening characteristics of moments decreasing with curvature are directly used, we encounter the troublesome situation that curvatures at the points reaching to yield moment can no longer increase and in consequence only elastic recovery can occur. This contradiction was pointed out by Wood ${ }^{\text {). }}$. And Wood $^{7)}$ and Barnard \& Johnson ${ }^{8)}$ indicated that it can be removed by introducing a small but finite region of highly localized strain softening at the points of peak moment, which was named the discontinuity line.

Here, introducing a discontinuity length denoted by $\Delta l$, we can replace the cross sectional characteristics of Fig. 1 by a plastic-strain softening hinge as shown in Fig. 2, Thus, putting

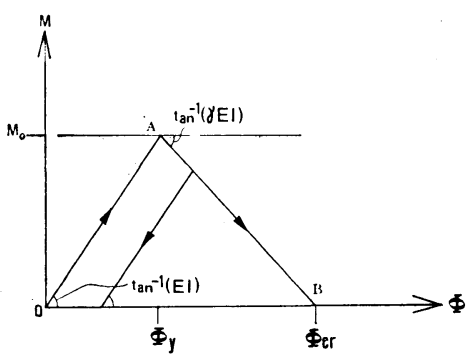

Fig. 1 Moment-curvature relation.

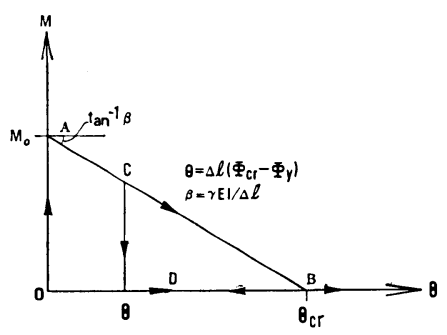

Fig. 2 Plastic-strain softening hinge.

$$
d W=\int_{V} f\left(d \varepsilon_{i j}\right) d V,
$$

Prob. (9) reduced, in a finite element analysis of beam bending, to

$$
\begin{aligned}
& \operatorname{minimize} \\
& \qquad \begin{array}{l}
d W=\frac{1}{2} \sum_{i} d \boldsymbol{\delta}_{i}^{t} \boldsymbol{K}_{i} d \boldsymbol{\delta}_{i}-\frac{1}{2} \sum_{i} \beta_{j} \Delta \theta_{j}^{2} \\
\text { subject to } \\
\quad \boldsymbol{a} d \boldsymbol{\delta}+\boldsymbol{b} \Delta \boldsymbol{\theta}=\mathbf{0} \\
\boldsymbol{P}_{0}^{t} d \boldsymbol{\delta}=d L, \quad \Delta \boldsymbol{\theta} \geq \mathbf{0}
\end{array}
\end{aligned}
$$

where $d \boldsymbol{\delta}_{i}$ is displacement-increments at the extremities of an element $i ; \boldsymbol{K}_{i}$ is element stiffness matrix; $\Delta \theta_{j}$ is plastic rotation-increment at a hinge $j$, which takes a positive value when its direction coincides with that of moment; $\beta_{j}$ is a coefficient of linear strain softening; $d \boldsymbol{\delta}^{t}=$ $\left[d \boldsymbol{\delta}_{1} d \boldsymbol{\delta}_{2} \cdots \cdots\right] ; \Delta \boldsymbol{\theta}^{t}=\left[\Delta \theta_{1} \Delta \theta_{2} \cdots \cdots \cdot\right] ;$ and $\boldsymbol{P}_{0}$ is a normalized load vector. The first equality constraint in Prob. (11) represents a compatibility between the plastic rotation-increment and the slope-increments at the adjacent extremities. Namely, in the case where $\Delta \boldsymbol{\theta}=\mathbf{0}$ identically, Prob. (11) is reduced to a purely elastic problem.

Further, to eliminate the free variables $d \delta$ from our problem, the following lagrangian function is introduced:

$$
F=d W+\boldsymbol{\mu}^{t}(\boldsymbol{a} d \boldsymbol{\delta}+\boldsymbol{b} \Delta \boldsymbol{\theta})+\mu_{0}\left(\boldsymbol{P}_{0}^{t} d \boldsymbol{\delta}-d L\right)
$$

where $\mu, \mu_{0}$ are Lagrange multipliers. Thus, from the stationary condition; $\partial F / \partial d \boldsymbol{d}=\mathbf{0}, \partial F /$ 
$\partial \boldsymbol{\mu}=\mathbf{0}$, and $\partial F / \mu_{0}=0$; Prob. (11) can be reduced to the following form:

$$
\begin{aligned}
& \text { minimize } \\
& \quad d \bar{W}=-d L \boldsymbol{A}^{t} \Delta \boldsymbol{\theta}+\Delta \boldsymbol{\theta}^{t} \boldsymbol{D} \Delta \boldsymbol{\theta} \\
& \text { subject to } \\
& \quad \Delta \boldsymbol{\theta} \geq \mathbf{0}
\end{aligned}
$$

Next, consider a solution of Prob. (13).

In Case 1 where $\boldsymbol{D}$ is positive definite, namely $\boldsymbol{\chi}^{t} \boldsymbol{D} \boldsymbol{\chi}>0$ for $0<|\boldsymbol{\chi}|<\infty$, the function of $d \bar{W}$ has a convexity. Then, there exists a unique solution, $\Delta \theta^{*}$, satisfying the following Kuhn-Tucker condition:

$$
\left.\begin{array}{l}
2 \boldsymbol{D} \Delta \boldsymbol{\theta}^{*}-d L \boldsymbol{A}-\boldsymbol{v}=\mathbf{0} \\
\Delta \boldsymbol{\theta}^{*} \geq \mathbf{0}, \quad \boldsymbol{v} \geq \mathbf{0}, \quad \Delta \boldsymbol{\theta}^{* t} v \geq \mathbf{0}
\end{array}\right\}
$$

where $\boldsymbol{v}$ is slack variables.

For this case, the methods of quadratic programming such as Wolfe's method or Beal's method ${ }^{11)}$ can be utilized.

In Case 2 where $\boldsymbol{D}$ is copositive, namely $\boldsymbol{\chi}^{t} \boldsymbol{D} \boldsymbol{\chi}>$ 0 for only $\boldsymbol{\chi}>\mathbf{0}$, the function $d \bar{W}$ has no convexity. However, a solution satisfying the condition (14) exists, because the function, $d \bar{W}$, is bounded in low. Namely, there is a stable equilibrium point in a local sense. For this case, Ritter's method $^{12)}$ for nonlinear programming may be utilized. A stability condition given by Maier ${ }^{2}$ is related with this case.

In Case 3 where $\boldsymbol{D}$ is neither positive definite nor copositive, Prob. (13) has no solution, because $d \bar{W}$ is unbounded in low. Namely, there is no stable equilibrium point in the strain softening domain $\mathrm{A}-\mathrm{B}$ in Fig. 2. Then, in this case, a jumping from the current state to a point in the domain $0-\mathrm{B}$ of no strength in Fig. 2 occurs after the elastic strain energy stored in the hinges was perfectly released.

Detailed procedures of numerical calculation related with the three cases mentioned above will be described through a simple example of a two-span beam in Fig. 3. According to an ordinary matrix displacement method, the beam is discretized by the three elements shown in Fig. 3. A plastic-strain softening hinge is possible at the points 1, 2, and 3. Thus, Problem (11) under an imposed deflection-increment $d u_{2}$ at the loading point 2 is expressed as

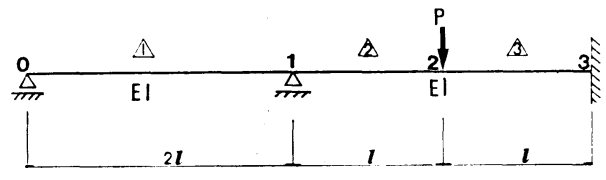

Fig. 3 Example of a two-span beam. minimize

$$
\begin{aligned}
& \frac{3 l}{2 E I} d W= \frac{9}{8} \varphi_{1 b}^{2}+\left(\varphi_{2 a}-\varphi_{2 b}\right)\left(2 \varphi_{2 a}+\varphi_{2 b}-3 \frac{d u_{2}}{l}\right) \\
&+\left(2 \varphi_{2 b}+\varphi_{2 a}-3 \frac{d u_{2}}{l}\right)^{2} \\
&+\left(\varphi_{3 a}-\varphi_{3 b}\right)\left(2 \varphi_{3 a}+\varphi_{3 b}+3 \frac{d u_{2}}{l}\right) \\
&+\left(2 \varphi_{3 b}+\varphi_{3 a}+3 \frac{d u_{2}}{l}\right)^{2} \\
&-\beta_{1}{ }^{\prime} \Delta \theta_{1}{ }^{2}-\beta_{2}{ }^{\prime} \Delta \theta_{2}{ }^{2}-\beta_{3}{ }^{\prime} \Delta \theta_{3}{ }^{2} \\
& \text { subject to } \quad \\
& \varphi_{2 a}-\varphi_{1 b}- \Delta \theta_{1}=0, \quad \varphi_{2 a}-\varphi_{3 a}-\Delta \theta_{2}=0, \\
& \varphi_{3 b}+\Delta \theta_{3}= 0, \quad P_{0} \frac{d u_{2}}{l}-d L=0, \\
& \Delta \theta_{1} \geqq 0, \quad \Delta \theta_{2} \geqq 0, \quad \Delta \theta_{3} \geqq 0 .
\end{aligned}
$$

where $\varphi_{i a}$ and $\varphi_{i b}(i=1,2,3)$ are slope-increment at the left and the right extremities of an element $i$, respectively, the positive sign of which is taken in the clockwise; $\Delta \theta_{j}(j=1,2,3)$ is plastic rotation-increment at a plastic-strain softening hinge $j$; and $\beta_{j^{\prime}}=3 l \beta_{j} / 4 E I(i=1,2,3)$, in which $E I$ is flexural rigidity.

Introducing the lagrangian function (12) given as

$$
\begin{aligned}
F= & d W^{\prime}+\mu_{1}\left(\varphi_{2 a}-\varphi_{1 b}-\Delta \theta_{1}\right) \\
& +\mu_{2}\left(\varphi_{2 b}-\varphi_{3 a}-\Delta \theta_{2}\right) \\
& +\mu_{3}\left(\varphi_{3 b}+\Delta \theta_{3}\right)+\mu_{0}\left(P_{0} d u_{2} / l-d L\right),
\end{aligned}
$$

where $d W^{\prime}=3 l d W /(2 E I)$,

and making its stationary condition; $\partial F / \partial \varphi_{i a}=$ $0, \partial F / \partial \varphi_{i b}=0, i=1,2,3$, and $\partial F / \partial \mu_{i}=0, i=1,2$, 3 ; we obtain the following relations:

$$
\begin{aligned}
{\left[\begin{array}{c}
\varphi_{1 b} \\
\varphi_{2 a} \\
\varphi_{2 b} \\
\varphi_{3 a} \\
\varphi_{3 b}
\end{array}\right] } & =\left[\begin{array}{r}
1.2^{-} \\
1.2 \\
-0.3 \\
-0.3 \\
0
\end{array}\right] \frac{d L}{P_{0}} \\
& +\left[\begin{array}{ccc}
-0.7 & -0.2 & -0.1 \\
0.3 & -0.2 & -0.1 \\
-0.075 & 0.55 & 0.275 \\
-0.075 & -0.45 & 0.275 \\
0 & 0 & -1.0
\end{array}\right] \cdot\left[\begin{array}{c}
\Delta \theta_{1}^{-} \\
\Delta \theta_{2} \\
\Delta \theta_{3}
\end{array}\right]
\end{aligned}
$$

where $d L / P_{0}=d u_{2} / l$.

Thus, the elimination of $\varphi_{i a}, \varphi_{i b}$ from Problem (15), using Eq. (17), gives the explicit form of Problem (13) with the following coefficient matrices:

$$
\boldsymbol{A}^{t}=\left(1 / P_{0}\right) \cdot\left[\begin{array}{lll}
2.7 & 7.2 & 8.1
\end{array}\right]
$$




$$
\boldsymbol{D}=\left[\begin{array}{lll}
0.7875-\beta_{1}{ }^{\prime} & 0.225 & 0.1125 \\
0.225 & 1.35-\beta_{2}{ }^{\prime} & 0.675 \\
0.1125 & 0.675 & 2.5875-\beta_{3^{\prime}}
\end{array}\right]
$$

A method of solution for this problem is described below. The following notations are used here: $\overline{\boldsymbol{D}}_{i i}$ is a submatrix derived by deleting $i$ column and $i$ row from $\boldsymbol{D}, \overline{\boldsymbol{A}}_{i}$ is a submatrix derived by deleting $i$ row from $\boldsymbol{A}$, and $d_{i i}$ is a diagonal element of $\boldsymbol{D}$.

Case $1 ; \quad|\boldsymbol{D}|>0,\left|\overline{\boldsymbol{D}}_{i i}\right|>0$ and $d_{i i}>0, \quad i=1,23$. For this case, an interation technique familiar in an ordinary elastic-plastic incremental analysis is available, even though an algolithm of quadratic programming is not used. Namely, solution; $\Delta \boldsymbol{\theta}=1 / 2 \cdot d L \boldsymbol{D}^{-1} \boldsymbol{A}$; is first obtained. If all elements of $\Delta \boldsymbol{\theta}$ are positive or zero, they are the required solution satisfying the condition (14). But, if $\Delta \theta_{i^{*}}, i^{*} \in i=1,2,3$, is negative, then $\Delta \theta_{i^{*}}$ is put to zero, and $\boldsymbol{D}$ and $\boldsymbol{A}$ are replaced by $\overline{\boldsymbol{D}}_{i^{*} i^{*}}$ and $\overline{\boldsymbol{A}}_{i^{*}}$, respectively. Thus, repetition of this procedure yields the required solution satisfying the condition (14). An example of solution

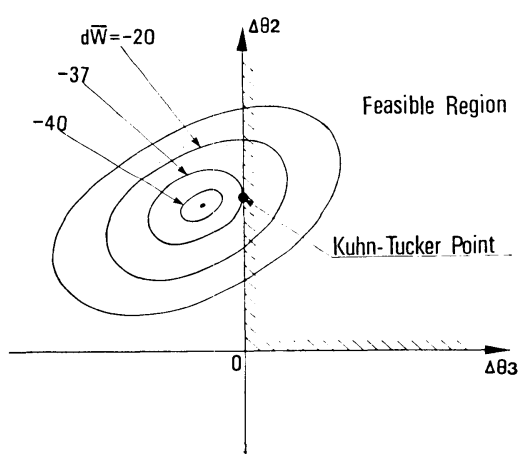

Fig. 4 Contour of $d \bar{W}$ and its minimum point in Case 1 with $\beta_{2}{ }^{\prime}=1.0$ and $\beta_{3}{ }^{\prime}=0.5$, under $d L / P_{0}=d u_{2} / l=1.0$.

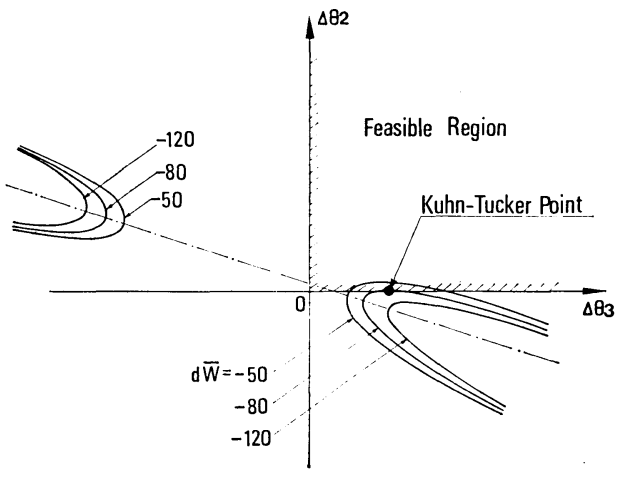

Fig. 5 Contour of $d \vec{W}$ and its minimum point in Case 2 with $\beta_{2}{ }^{\prime}=1.2$ and $\beta_{3}{ }^{\prime}=0.5$, under $d L / P_{0}=d u_{2} / l=1.0$. is indicated with the contour of $d \bar{W}$ in Fig. 4 for a problem where plastic-strain softening hinges occurred at the points 2 and 3 .

Case 2; $|\boldsymbol{D}|<0$ or $\left|\overline{\boldsymbol{D}}_{i i}\right|<0$ and $d_{i i}>0$. Since all of nondiagonal elements of $\boldsymbol{D}$ are positive, $\boldsymbol{D}$ is copositive, if and only if all the diagonal elements $d_{i i}$ are positive. In this case, a KurnTucker point is necessarily on the constraint surface, $\Delta \theta_{i^{*}}=0$. Then, finding $i^{*}, i^{*} \in i$, where $\overline{\boldsymbol{D}}_{i^{*} i^{*}}$ becomes positive definite, we can obtain the required solution through a similar procedure to that of Case 1. An example of solution in Case 2 is indicated with the contour of $d \bar{W}$ in Fig. 5 for a problem including the hinges at the points 2 and 3 .

Case $3 ; d_{i i} \ngtr 0$. The function $d \bar{W}$ is unbounded in low, as seen in the contour of Fig. 6 for an example problem. In this case, a strain energy stored in a hinge $i^{*}$ where $d_{i^{*} i^{*}}<0$ is abruptly released, and therefore the function of strain energy-increment is reduced to

$$
d \bar{W}=\bar{M}_{i *} \Delta \theta_{i^{*}}-d L \boldsymbol{A}^{t} \Delta \boldsymbol{\theta}+\left.\Delta \boldsymbol{\theta}^{t} \boldsymbol{D}\right|_{\beta^{\prime} i^{*}=0} \Delta \boldsymbol{\theta}
$$

where $\bar{M}_{i^{*}}=3 l M_{i^{*}} /(2 E I), M_{i^{*}}$ is moment at the hinge $i^{*}$ in the current state. The reduced matrix with $\beta^{\prime}{ }^{*}=0$ in Eq. (19) becomes positive definite or copositive, then our problem also returns to Case 1 or Case 2. But, in this case, the solution $\Delta \boldsymbol{\theta}$ is not zero even when the imposed displacement-increment $\mathrm{dL}$ vanishes, thus a jumping from a plastic hinge to a freely rotating hinge with no strength results, such as a skip from the point $\mathrm{C}$ to the point $\mathrm{D}$ in Fig. 2.

\section{NUMERICAL CALCULATION}

Relations between load or bending moment and displacement in the two-span beam with a uniform flexural rigidity, as shown in Fig. 3, are illustrated in Figs. 7, 8, and 9. In these figures;

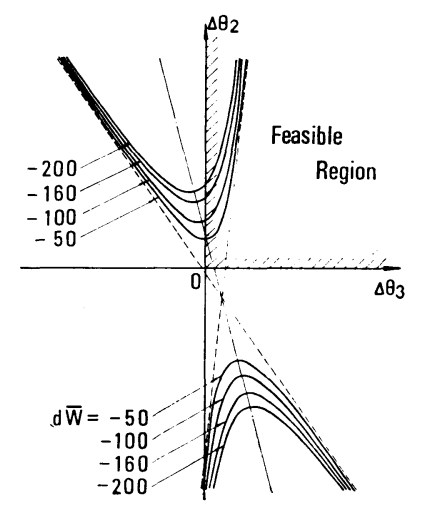

Fig. 6 Contour of $d \bar{W}$ in Case 3 with $\beta_{2}{ }^{\prime}=1.5$ and $\beta_{3}{ }^{\prime}=0.5$, under $d L / P_{0}=d u_{2} / l=1.0$. 


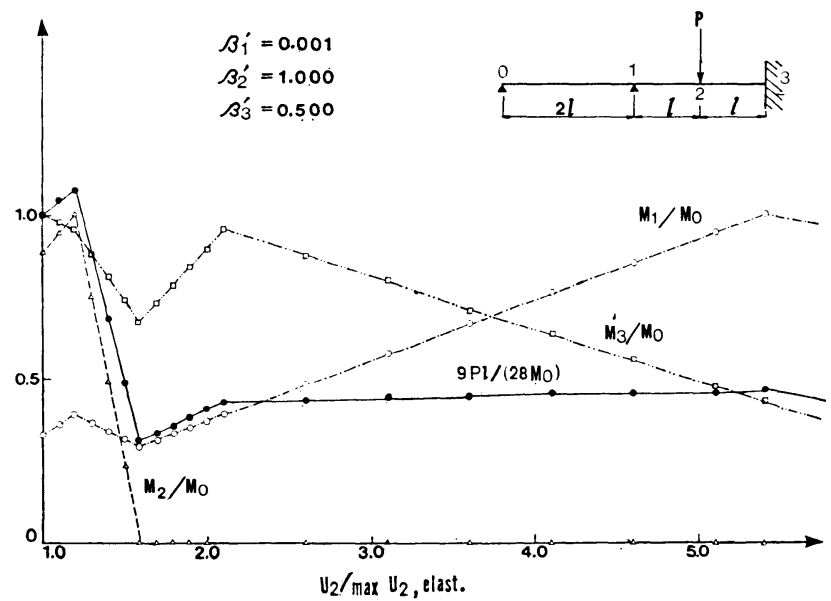

Fig. 7 Relations between bending moments or load and deflection for the problem including only Case 1 .

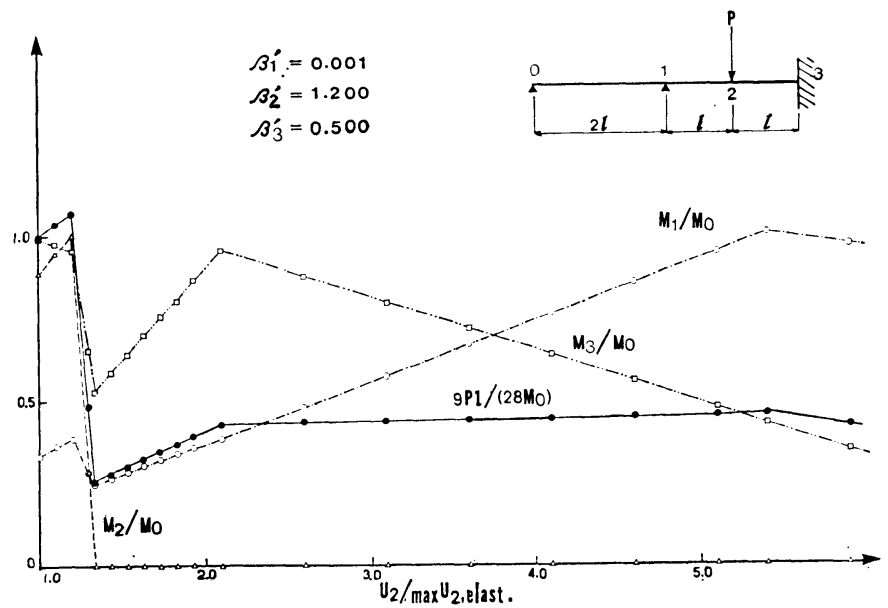

Fig. 8 Relations between bending moments or load and deflection for the problem including both Case 1 and Case 2 .

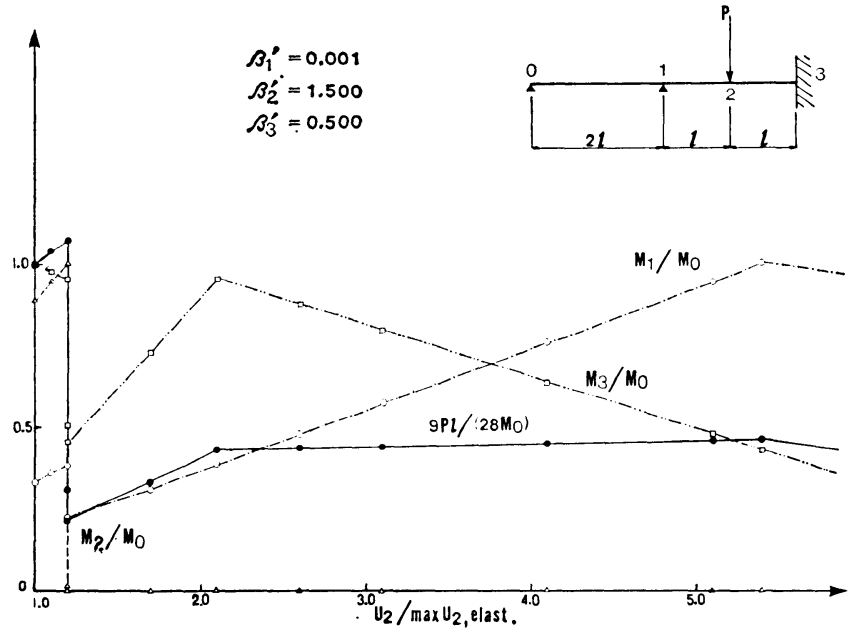

Fig. 9 Relations between bending moments or load and deflection for the problem including Case 1, Case 2, and Case 3. 
$M_{i}(i=1,2,3)$ shows bending moment at the point $i, M_{0}$ and $\beta^{\prime} i\left(=3 l \beta_{i} / 4 E I, E I\right.$ is flexural rigidity) are yield moment and strain softening coefficient as defined in Fig. 2, $u_{2}$ is deflection at the loading point, and $\max u_{2 \text {, elast. means the }}$ value of $u_{2}$ at the first yielding at the point 3 .

Fig. 7 shows a problem where all of loading stages are included in only Case 1 mentioned before, and the problem of Fig. 8 includes both Case 1 and Case 2. It should be noted in these problems that the intensities of load and bending moments have a single value under a specified deflection, namely the uniqueness of solution is obtained in all loading stages.

On the other hand, the problem of Fig. 9 including Case 1, Case 2, and Case 3 no longer yields such a uniqueness of solution. Thus, a jumping of both the load and the bending moments under a constant value of deflection can be seen in this problem.

\section{CONCLUDING REMARKS}

A bending theory for elastic-plastic strain softening beams of statically indeterminancy is developed. A detailed procedure of numerical calculation based upon this theory is described through a simple example of a two-span beam. The procedure is applicable to a problem with large degrees of statically indeterminancy, except for the case where the nondiagonal elements of $\boldsymbol{D}$ in Prob. (13) include negative values. In such a case, some troublesome works are needed in connection with a nonconvex quadratic programming. Although this type of problem remains unsolved, it is believed that the procedure presented here gives an effective bridge to a general method.

\section{ACKNOWLEDGEMENT}

The author wishes to express many appreciations to Prof. Giulio Maier of Politecnico di Milan, Italy for supplying copies of the papers ${ }^{2,3)}$ written by the professor.

\section{NOTATION}

$d W:$ strain energy increment.

$d \pi$ : potential energy increment.

$d \boldsymbol{\delta}$ : vector of overall extremity-displacement increments in elements.

$\Delta \theta$ : vector of overall rotation increments at strain-softening hinges.

$\varphi_{i a}, \varphi_{i b}$ : element of $d \boldsymbol{\delta}$, namely extremity-displacement increments at the left and the right ends of element $i$, respectively.
$\Delta \theta_{j}$ : element of $\Delta \boldsymbol{\theta}$, namely rotation increment at plastic strain-softening hinge $i$.

$\boldsymbol{K}_{i}$ : element stiffness matrix.

$\boldsymbol{P}_{0}$ : normalized load vector.

$d L$ : controlled displacement increment defined by Eq. (8).

$F$ : lagrangian function defined by Eq. (12).

\section{REFERENCES}

1) Prevost, J. H. and K. Höeg: Soil Mechanics and Plasticity Analysis of Strain Softening, Géotechnique, Vol. 25, No. 2, pp. 279 297, 1975.

2) Maier, G.: On Structural Instability Due to Strainsoftening, IUTAM Symposium Herrenalb 1969; Instability of Continuous Systems (H. Leipholz, ed.), Springer-Verlag, pp. 411 417, 1971.

3) Maier, G.: Sul comportamento flessionale instabile nelle travi inflesse elastoplastiche, Istituto Lombardo di Scienze e Lettere (Rend. Sc.-A), Vol. 102, pp. 648 177, 1968 (in Italian).

4) Nayak, G. C. and O. C. Zienkiewicz: ElastoPlastic Stress Analysis. A Generalization for Various Constitutive Relations Including Strain Softening, Int. J. Num. Meth. Engng., Vol. 5, No. 1, pp. 113 135, 1972.

5) Pietruszczak, St. and Z. Mroz: Finite Element Analysis of Deformation of Strain-softening Materials, Int. J. Num. Meth. Engng., Vol. 17, No. 3, pp. 327 334, 1981.

6) Kawamoto, T. and Y. Ishizuka: An Analysis of Excavation in Strain-softening Rock Mass, Proc. of the Japan Society of Civil Engineers, No. 312, pp. $107 \sim 118,1981$.

7) Wood, R. H.: Some Controversial and Curious Developments in the Theory of Structures, Engineering Plasticity, J. Heymann and F. A. Lekie Ed., Cambridge Univ. Press, pp. 665 691, 1968.

8) Barnard, P. R. and R. P. Johnson: Plastic Behaviour of Continuous Composite Beams, Proc. of Institute of Civil Engineers, Vol. 32, pp. 180 197, 1965.

9) Ghosh; S. K. and M. Z. Cohn: Non-Linear Analysis of Strain-Softening Structures: Symposium on Inelasticity and Non-Linearity in Structural Concrete (M. Z. Cohn, ed.), University of Waterloo Press, pp. 315 332, 1972.

10) Sonoda, K.: Circular Slabs with Limited Plastic Flow Capacity, IABSE Colloquium Copenhagen 1979, Plasticity in Reinforced Concrete, pp. 145 152, 1979.

11) Saaty, T. L. and J. Bram: Nonlinear Mathematics, McGraw-Hill, Book Co., Inc., p. 93, 1964.

12) Ritter, K.: A Method for Solving MaximumProblems with a Nonconcave Quadratic Objective Function, Z. Wahrscheinlichkeitstheorie verw. Gebiete, Vol. 4, pp. 340 351, 1966.

(Received August 4, 1982) 
和交要旨

\section{ひずみ軟化を有する \\ はりの曲げ解析}

（園田恵一郎）

論交報告集, 第 337 号, 1983 年 9 月

コンクリート，土や岩などの材料は，圧縮荷重の作用 下で，ひずみ軟化挙動を示すことはよく知られている. たとえばコンクリートの円柱供試体の圧縮試験での応 力・ひずみ曲線は約 $0.25 \%$ のひずみを越えたところか ら圧壊の始まる約 $0.35 \%$ の間で降下領域をもっている. このようなひずみ軟化挙動は物理的な不安定現象である から,ひずみ軟化材料から成る構造物の応力および変形 解析では, 解の安定性や唯一性の問題にしばしば遭遇す る.

たとえば, 有限要素变位解析法における最終段階での 方程式は次のように表わされる.

$$
\boldsymbol{P}=\boldsymbol{K} \boldsymbol{u}
$$

ここに, $\boldsymbol{P}$ は規定された節点力または節点変位, $\boldsymbol{u}$ は未 知の節点力または節点変位, $\boldsymbol{K}$ は全体剛性行列である.

$\boldsymbol{K}$ は構造形状と材料特性によって決まる行列であるか ら，ひずみ軟化特性にも影響を受ける。もし， $\boldsymbol{K}$ が正值 (positive definite) である場合は, 式 (1) の未知量 $\boldsymbol{u}$ は次 式で唯一に決定できる.

$$
\boldsymbol{u}=\boldsymbol{K}^{-1} \boldsymbol{P}
$$

しかし， K が正值でない場合には，式 (2)はもはや安定 なつり合い解を与えない. すなわち, この場合は, 全体 系のひずみエネルギーを与える関数が凸性を失い,式 (2) の解が系のポテンシャルエネルギーを最小にする点に対 応していないからである。

弾塑性・ひずみ軟化ばりのマトリックス変位法による 曲げ解析においては, 節点力増分と節点变位増分の間に 式 (1) と類似した関係が成立する. 本論文は，モーメン トと曲率の間に軟化挙動を有するはりに対して，軟化の
程度と $\boldsymbol{K}$ の特性との関係および対応する安定なつり合 い解の決定法について述べたものである。

最初に，たわみ増分の制御のもとでのひずみエネルギ 一の最小化原理について述べた。次に，はりの曲げ問題 に対して, 塑性軟化ヒンジ（回転角の増加につれてモー メントが減少する特性をもつヒンジ）を導入し，マトリ ックス変位法による上述の最小化原理の定式化を試み た. 得られた式中の未知量は塑性軟化ヒンジでの回転角 増分, 分割された各要素の材端変位増分および荷重増分 である.ラグランジュの未定係数法により自由变数であ る材端变位増分を消去し, 制約不等式をもつ回転角増分 のみを変数にした問題に変換すると次の形を得る.

$$
\begin{array}{ll}
\text { minimize } & d \vec{W}=-d L \boldsymbol{A}^{t} \Delta \boldsymbol{\theta}+\Delta \boldsymbol{\theta}^{t} \mathrm{D} \Delta \boldsymbol{\theta} \\
\text { subject to } & \Delta \boldsymbol{\theta} \geq \mathbf{0}
\end{array}
$$

ここに, $\Delta \theta$ は塑性軟化ヒンジの回転角, $d L$ はたわみ増 分を与えるパラメーター, $\boldsymbol{A}, \boldsymbol{D}$ は軟化率を含む係数行 列である。

式 (3) の問題の解の決定には, 次の 3 つの場合に対し て，それぞれ異なった取扱いが必要である.

（1） D が正值 (positive definite)の場合

式 (3) は標準的な 2 次計画法 (Quadratic Programming) の問題になり, 周知の手法で唯一解が求められる.

（2） D が共正值 (copositive)の場合

$d \bar{W}$ は凸関数でないが, 領域 $\Delta \theta \geq 0$ では下に有界であ るので, 式 (3) は解をもつ.

（3） $\boldsymbol{D}$ が正值でも共正值でもない場合

$d \bar{W}$ は下に有界でない。したがって, 式 (3) は解をも たない。すなわち，この場合は，一部の塑性軟化ヒンジ がひずみエネルギーを解放し，モーメントに抵抗しない ヒンジになって, 不安定な系は新しい安定系に移行する. したがって，一定のたわみのもとで，荷重および曲げモ 一メント分布に飛移が起こる.

2 径間連続ばりの簡単な問題を通して上記の 3 つのケ 一スに対する解の決定法を示し, 数值計算例により, 各 ケースに対する荷重とたわみおよび曲げモーメントの関 係を示した。 